\title{
HIERACIUM GLABRESCENS (ASTERACEAE) REDISCOVERED IN THE CARPATHIANS
}

\author{
ZBIGNIEW SZELĄG
}

\begin{abstract}
The occurrence of Hieracium glabrescens (F. W. Schultz) Murr in the Carpathians is confirmed after over a century by a new locality from the Apuseni Mountains in Romania. This locality, very significant from the phytogeographical point of view, is disjoined $\mathrm{ca} 500 \mathrm{~km}$ from the nearest Balkan localities of the species. The origin of $H$. glabrescens in the Apuseni Mountains is briefly discussed.
\end{abstract}

Key words: Carpathians, distribution, Hieracium glabratum s.1., new relict locality, Romania

Zbigniew Szelag, Pedagogical University of Cracow, Department of Botany, Podchorążych 2, 30-084 Kraków, Poland; e-mail: azszelag@wp.pl

In July 2005, during field studies in the Apuseni Mountains in central Transilvania, Romania, I found a population of Hieracium glabrescens (F. W. Schultz) Murr (= H. glabratum subsp. nudum Nägeli \& Peter) (Fig. 1). It is the only known extant occurrence of the species in the entire Carpathians (Fig. 2), discovered nearly 130 years since the first and only report to date. It is located in the middle part of the Cheile Ordâncuşei gorge $\left(46^{\circ} 28^{\prime} 20^{\prime \prime} \mathrm{N}, 22^{\circ} 50^{\prime} 47^{\prime \prime} \mathrm{E}\right)$ at $c a 800 \mathrm{~m}$ a.s.l. Hieracium glabrescens grows on calcareous rocks along the road which runs along the bottom of the gorge on its $150 \mathrm{~m}$ long stretch, together with Sesleria filifolia Hoppe, Carex capillaris L., Minuartia setacea subsp. bannatica (Rchb.) Nyár., Hieracium bifidum s.1., Cortusa matthioli L., Carduus defloratus L. More individuals of it are likely to be found also on the poorly accessible slopes rising 100-200 $\mathrm{m}$ above the gorge bottom. In 2014 the population in the Cheile Ordâncuşei gorge consisted of about 40 flowering plants and numerous non-flowering one.

The first information about the occurrence of Hieracium glabratum s.l. in Romania was given by Nägeli and Peter (1886), who reported two taxa: H. glabratum subsp. nudum Nägeli \& Peter from the Bucegi Mountains, from Mt. Chiruşca in the Ciucaş Mountains, and from the Rodna Mountains, and $H$. glabratum subsp. pseudoflexuosum Nägeli \& Peter from the Bucegi Mountains. Zahn (1921-1923, 1930-1935) and later Nyárády (1965) only repeated Nägeli and Peter's (1886) data. Zahn (1930-1935) stated that he had personally seen a H. glabrescens specimen from the Ciucaş Mountains only.

Ferdinand Pax (1858-1942), an explorer of the Carpathians and expert on the genus Hieracium, placed in doubt the occurrence of $H$. glabratum [s.1.] in Romania at all (cf. Pax 1908: 93), which means that he had not seen the specimens on which Nägeli and Peter (1886) based their data. I also have been unable to trace any specimens belonging to H. glabratum s.l. (or labeled H. glabratum) that were collected in Romania, in several European herbaria (BP, BRNM, KRA, KRAM, PR, PRC, $\mathrm{W}, \mathrm{WU}, \mathrm{WRSL}$ ), including the main Romanian herbaria of the Babeş-Bolyai University in ClujNapoca (CL) and Institute of Biology, Romanian Academy in Bucharest (BUCA).

In 2014 and 2015 I searched without results for $H$. glabrescens in the Ciucaş Mountains, including twice on Mt. Chiruşca. The only Hieracium species 


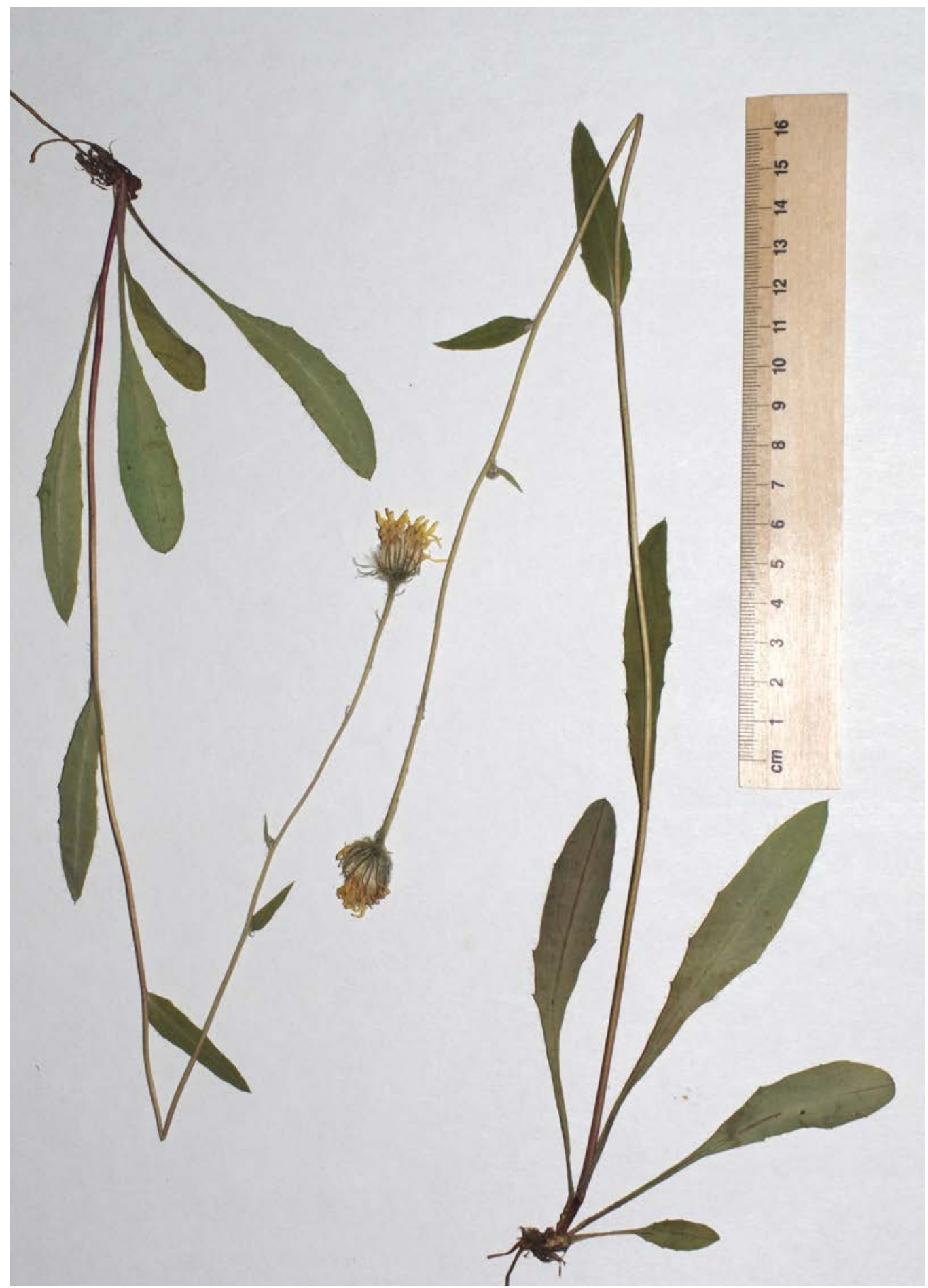

Fig. 1. Specimen of Hieracium glabrescens (F. W. Schultz) Murr from the Apuseni Mts. 


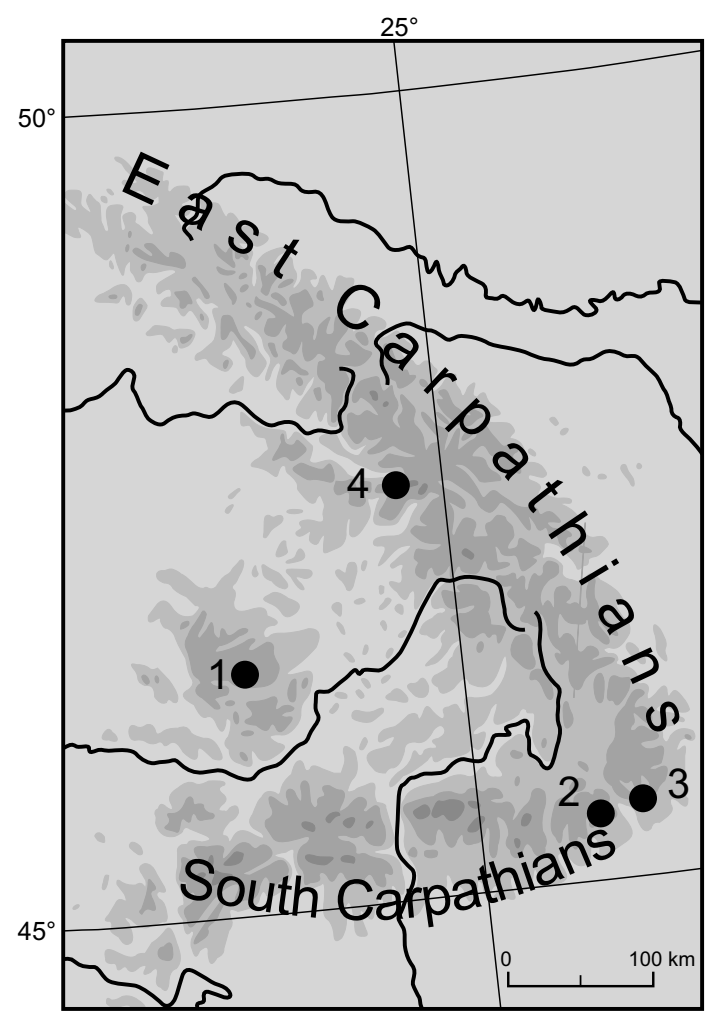

Fig. 2. Distribution of Hieracium glabrescens (F. W. Schultz) Murr in the Carpathians. 1 - Apuseni Mts (new locality), 2 - Bucegi Mts, 3 - Ciucaş Mts, 4 - Rodna Mts.

that is commonly present on Mt. Chiruşca is $H$. villosum Jacq.

The geographical range of $H$. glabrescens comprises limestone ranges of the Alps, with the center in the Eastern Alps, northern part of the Apennines and western part of the Balkan Peninsula (Croatia, Bosna and Hercegovina, Montenegro, Albania, Macedonia) (Zahn 1930-1935). It also grows in the Abruzzo Mountains in central Italy (Gottschlich 2009). The new locality of $H$. glabrescens in the Apuseni Mountains is about $500 \mathrm{~km}$ distant from its closest counterparts in Macedonia and Montenegro.
The population of Hieracium glabrescens in the Apuseni Mountains is without doubt a relict. Its age is at least late-glacial, as this was the last time when mountain flora migration was possible between the Apuseni Mountains and Dinaric Mountains. It is possible, however, that the history of H. glabrescens in the Apuseni Mountains is even longer than the end of the last glaciation. The occurrence of the relict pre-glacial and glacial populations of calciphilous flora species in the Apuseni Mountains was discussed by Csergő (2002).

AcKnowledgements. I am grateful to Dr. Günter Gottschlich (Tübingen) for his help with literature, Dr. Sorin Ştefãnuţ (Bucharest) for information about the Hieracium glabratum collection in BUCA, and the anonymous referees for helpful suggestions on the manuscript.

\section{REFERENCES}

CSERGö A.-M. 2002. The problem of the refugia of certain preglacial and glacial relict populations from the calciphilous flora of the Apuseni Mountains (Romania). Contribuţii Botanice 37: 251-262.

Gotтschlich G. 2009. Die Gattung Hieracium (Compositae) in der Region Abruzzen (Italien). Stapfia 89: 1-328.

NäGeli C. v. \& Peter A. 1886. Die Hieracien Mittel-Europas. Monographische Bearbeitung der Archieracien. R. Oldenbourg, München.

NyÁrÁdy E. I. 1965. Hieracium L. In: E. I. NyÁRÁDy (ed.), Flora Republicii Populare Romîne. 10: 214-746. Editura Academiei Republicii Populare Romîne, Bucureşti.

PAx F. 1908. Grundzüge der Pflanzenverbreitung in den Karpathen. 2. In: A. Engler \& O. Drude (eds), Die Vegetation der Erde. 10. W. Engelmann, Leipzig.

ZaHN K. H. 1921-1923. Hieracium L. In: A. Engler (ed.), Das Pflanzenreich Regni Vegetabilis Conspectus. 4(280): 1-1146. W. Engelmann, Leipzig.

ZAHN K. H. 1930-1935. Hieracium L. In: P. GraebNer FIL. (ed.), Synopsis der mitteleuropäischen Flora. 12(2): 1-790. Borntraeger, Leipzig. 